Gut, 1982, 23, 1029-1036

\title{
Lymphocyte cytotoxicity to autologous hepatocytes in HBsAg positive chronic liver disease
}

\author{
GIORGINA MIELI-VERGANI, D VERGANI, B PORTMANN, \\ YVETTE WHITE, I MURRAY-LYON, J H MARIGOLD, I WOOLF, \\ A L F W EDDLESTON, and ROGER WILLIAMS \\ From The Liver Unit, King's College Hospital and Medical School, Denmark Hill, London
}

\begin{abstract}
SUMMARY Lymphocytes from 39 patients with HBsAg positive chronic liver disease were incubated with their own hepatocytes to investigate mechanisms of lymphocyte-mediated liver damage. Cytotoxicity was significantly increased in $46 \%$ overall, and in $73 \%$ of those with chronic active hepatitis. Unlike HBsAg negative chronic active hepatitis where only non-T cells were cytotoxic, HBsAg positive patients had both cytotoxic $\mathrm{T}$ and non-T cells. A purified liver membrane complex (LSP) and aggregated IgG both blocked non-T cytotoxicity without affecting $T$ cell cytotoxicity; this suggests that the former is probably an antibody-dependent cell-mediated reaction against normal membrane components. This was confirmed in preliminary studies which demonstrated that preincubation of hepatocytes with the $\mathrm{F}(\mathrm{ab})_{2}^{\prime}$ fragment of an anti-human IgG reduced non-T lymphocyte cytotoxicity. T-cell cytotoxicity was restricted to $\mathrm{HBeAg}$-positive patients, suggesting a relationship between $\mathrm{T}$-cell cytotoxicity and viral replication. Purified HBsAg, however, blocked cytotoxicity in only three of 11 cases. Non-T lymphocytes reacting with normal membrane components may contribute to liver damage in both 'autoimmune' and virus-associated chronic liver disease, whereas cytotoxic T-cells, probably reacting with viral determinants, are exclusive to those with viral replication.
\end{abstract}

In the investigation of immune reactions to liver cell membrane antigens, one approach is to incubate hepatocytes with peripheral blood lymphocytes from patients and to look for cytotoxic effects. ${ }^{1-4}$ Primary cultures of adult hepatocytes are very difficult to establish, and radiolabelled freshly isolated liver cells show such a high and variable spontaneous release of chromium that an isotope release assay becomes insensitive and unreliable. Cell lines derived from primary hepatocellular carcinomas are more viable but have variable expression of normal membrane components such as liver specific lipoprotein ${ }^{5}$ (LSP) and are very sensitive to the cytotoxic effect of natural killer cells. ${ }^{6}$ The high level of natural killer cytotoxicity when the cell lines are used as targets may mask specific immune reactions; as an alternative approach we have developed a microcytotoxicity assay in which hepatocytes freshly isolated from diagnostic liver biopsies are used as target cells. To

Received for publication 1 March 1982 ensure histocompatibility between target and effector cells, which is probably required for optimum T cell cytotoxicity, ${ }^{7}$ we have incubated these hepatocytes with the patients' own lymphocytes. ${ }^{8}$ We report here the results obtained with this autologous cytotoxicity assay in patients with a variety of liver diseases associated with chronic hepatitis B virus infection.

\section{Methods}

\section{PATIENTS}

Thirty-nine HBsAg positive patients were studied (34 men, mean age 32.9 years, range $17-69$ years; five women, mean age 26.4 years, range 10-38 years). Of these, $27(69 \%)$ had been found to be HBsAg positive on screening of high risk groups and had remained $\mathrm{HBsAg}$ positive for two to 72 months (median nine months). On review one year after the biopsy had been performed all patients had remained HBsAg positive. The other 12 had been persistently HBsAg positive after an acute hepatitis from seven to 228 months previously (median 26 
months). All had persistently or intermittently abnormal liver function tests; a liver biopsy was performed for diagnostic purposes in all patients. None of the patients had received any immunosuppressive treatment before biopsy. Risk factors for acquiring the infection included male homosexuality (17 patients), drug addiction (three), tattoos (three), medical personnel (one), blood transfusion (one) (Table 1). Liver histology was assessed by a pathologist (BP) without prior knowledge of the biochemical or immunological findings, and the cytotoxicity values were calculated before the liver biopsy result was known. Each biopsy was scored for the following: mononuclear cell portal tract infiltrate, piecemeal necrosis, lobular infiltrate, lobular liver cell necrosis, liver cell hyperplasia, and fibrosis (absent $=0$, mild $=1$, moderate $=2$, severe $=3$ ). Patients were also allocated to one of four diagnostic categories: minor histological abnormalities, chronic persistent hepatitis, chronic active hepatitis, and chronic lobular hepatitis. Chronic persistent hepatitis and chronic active hepatitis were diagnosed according to internationally agreed criteria. ${ }^{9}$ Many of the patients classified as having chronic lobular hepatitis had portal tract changes similar to those found in chronic persistent hepatitis or chronic active hepatitis, but the main features were inflammation and liver cell damage scattered throughout the lobule.

HBsAg positivity was tested by Elisa (enzymelinked immunosorbent assay, Auszyme, Abbott), and the titre was determined by passive haemagglutination (Hepatest, Wellcome). HBeAg and anti-HBe were tested by radioimmunoassay (RIA, Abbott, HBe). Thirty-seven of the 39 patients who were $\mathrm{HBsAg}$ positive according to Elisa were also positive as shown by haemagglutination, with titres ranging from 200 to 80000 (median 12 800) (Table 1). Twenty-one were $\mathrm{HBeAg}$ positive and 10 were anti-HBe positive. Anti-HBe was found mainly in patients with mild histological abnormalities, although it was also present in three patients with chronic active hepatitis. $\mathrm{HBeAg}$ was found in all patients with chronic lobular hepatitis, in about half of those with chronic persistent hepatitis and chronic active hepatitis, but in only two of the 12 patients with mild histological abnormalities (Table 1).

PREPARATION OF LYMPHOCYTES AND

MICROCYTOTOXICITY ASSAY

Fifty millilitres of blood were taken at the time of biopsy and leucocyte rich plasma was obtained by sedimentation with $5 \mathrm{ml}$ of $6 \%$ dextran containing $600 \mathrm{U}$ of preservative-free heparin, and kept at room temperature. Twenty-four hours later, after dilution 1:1 with RPMI 1640 medium with glutamine (Flow Laboratories Ltd) the leucocyte-rich plasma was incubated in a cotton-wool column at $37^{\circ} \mathrm{C}$ for 15 minutes to remove macrophages. ${ }^{10}$ The leucocytes were then centrifuged over a FicollTriosil density gradient to remove the remaining neutrophils and red blood cells. ${ }^{11}$ After washing, the interface lymphocytes excluded trypan blue and contained less than $1 \%$ neutrophils and less than $5 \%$ macrophages. Subpopulations of lymphocytes were obtained by the method described previously. ${ }^{4} \mathrm{~A}$ T-cell enriched lymphocyte subpopulation was obtained by removing the cells bearing receptors for complement after rosetting with sheep red blood cells previously coated with the total immunoglobulin fraction of anti-sheep red blood cell serum and complement (EAC). The non-rosetted $T$ cells were collected at the interface after centrifugation over a Ficoll-Triosil density gradient. In 23 experiments $\mathrm{T}$ cells were further purified: complementreceptor-bearing cells were first removed as described above but with IgM anti-sheep red blood cell antibody and complement, and then Fc-receptor bearing lymphocytes were removed by rosetting with sheep red blood cells coated with the total immunoglobulin fraction of anti-sheep red blood cell antiserum (EA). A non-T-cell enriched subpopulation was obtained by removing, on FicollTriosil, $T$ lymphocytes after rosetting with sheep red blood cells. We have previously shown that $\mathrm{T}$ and non- $T$ fractions prepared according to these techniques are contaminated with between 1 and $9 \%$ of non- $\mathrm{T}$ cells and between 1 and $25 \%$ of $\mathrm{T}$ cells respectively. ${ }^{8}$

The technique used for the microcytotoxicity assay was similar to that described previously. ${ }^{8}$ Two to three millimetres of human liver biopsy were used for the preparation of isolated hepatocytes. The liver was incubated at $37^{\circ} \mathrm{C}$ for four to five hours in RPMI- 1640 containing $10 \%$ fetal calf serum, $0.01 \%$ collagenase, $1 \mathrm{M}$ Hepes $2.3 \%$, penicillin $200 \mathrm{U} / \mathrm{ml}$, streptomycin $100 \mu \mathrm{g} / \mathrm{ml}$, and amphotericin B 2 $\mu \mathrm{g} / \mathrm{ml}$, adjusted to a $\mathrm{pH}$ of $7.35 \mathrm{in}$ an atmosphere of $95 \% \mathrm{O}_{2}$ and $5 \% \mathrm{CO}_{2}$. After washing with RPMI 1640 medium, $10 \mu \mathrm{l}$ of the isolated hepatocyte preparation was placed into each well of a microculture plate (Falcon 3034) to achieve a final concentration of about 100 cells per well and incubated in an atmosphere of $95 \% \mathrm{O}_{2}$ and $5 \% \mathrm{CO}_{2}$ at $37^{\circ} \mathrm{C}$. After 24 hours, the supernatant was aspirated from each well and replaced in at least 10 test chambers with $10 \mu$ l of lymphocytes suspended in RPMI 1640 medium with $10 \%$ fetal calf serum. Controls were at least 10 wells with hepatocytes plus medium alone. The concentration of lymphocytes 
was adjusted to produce a lymphocyte to hepatocyte ratio of 300:1. In 11 experiments a lower ratio (100:1) was also used when $T$ cells were incubated with hepatocytes. Blocking experiments were performed in which $1 \mu \mathrm{g}$ of liver-specific lipoprotein was added to each test well. This was prepared as described previously ${ }^{12}$ except for the addition of a further purification step - namely, chromatography over Sepharose 2B, the material in the excluded volume being used in these blocking studies. Blocking experiments were also performed with 5 $\mu \mathrm{g}$ of heat-aggregated $\operatorname{IgG}^{13}$ or $0.5 \mu \mathrm{g}$ of purified HBsAg, prepared as described before. ${ }^{14}$ In some cases blocking studies were also performed preincubating the hepatocytes for two hours with $12 \mu \mathrm{g}$ of an $\mathrm{F}(\mathrm{ab})_{2}^{\prime}$ fragment of an antibody to human IgG, prepared according to Farr and Nakane. ${ }^{15}$

After incubation at $37^{\circ} \mathrm{C}$ for a further 48 hours, the plates were inverted for one hour and then gently washed with medium. The number of hepatocytes left in each well was counted at $\times 60$ magnification using a graticule eyepiece. The difference between the mean number of cells in control wells and that in test wells expressed as a fraction of the former gave the percentage cytotoxicity. In four cases T-cell cytotoxicity was also calculated after six hours' incubation and in 11 after 18 hours' incubation.

The normal range was determined with lymphocytes and hepatocytes from $11 \mathrm{HBsAg}$ negative patients who were biopsied for diagnostic purposes, but showed no significant histological abnormalities (two patients with Gilbert's syndrome, two investigated for mild disturbances in liver function tests, three follow-up biopsies after acute hepatitis, one follow-up patient with granulomatous disease, one with diabetes, one with psoriasis before starting treatment with methotrexate, one with portal vein thrombosis). The upper limit of normal in such a system calculated as 2 standard deviations above the mean was $32 \%$ for the undivided lymphocyte population, $32 \%$ for $\mathrm{T}$ cells, and $24 \%$ for non- $\mathrm{T}$ cells.

\section{Results}

Eight of the 11 patients $(73 \%)$ with chronic active hepatitis had significantly increased lymphocyte cytotoxicity to autologous hepatocytes but this was uncommon in those with mild histological abnormalities (two of $12,17 \%)\left(\chi^{2}=7 \cdot 34, p<0 \cdot 001\right)$. Patients with chronic persistent and chronic lobular hepatitis had intermediate values for frequency of cytotoxicity (Fig. 1). Although only those patients with chronic active or chronic lobular hepatitis had cytotoxicity values greater than $50 \%$, there was no

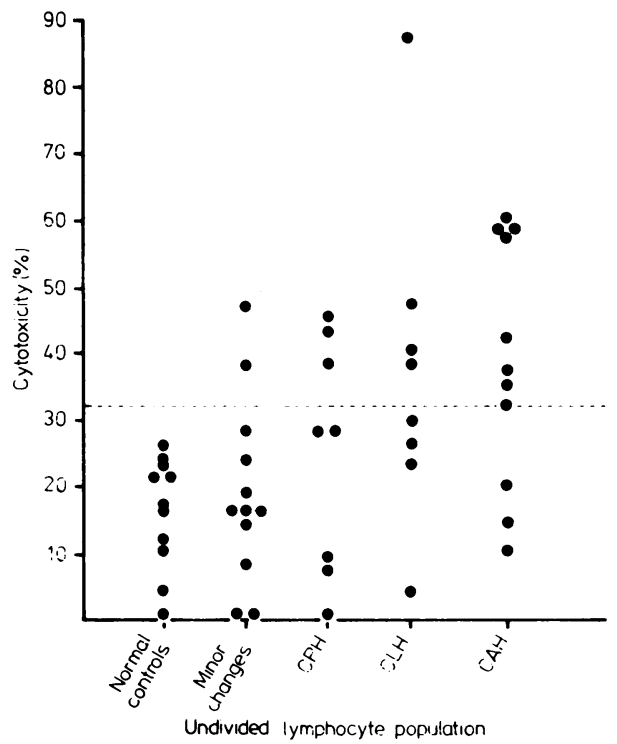

Fig. 1 Results of the autologous cytotoxicity assay using peripheral blood lymphocytes in the different patient groups.

significant correlation between diagnostic categories and the extent of the cytotoxicity in vitro (Fig. 1).

Subpopulations of the lymphocytes were prepared in all of the 39 cases. Of the 16 patients with increased cytotoxicity with the undivided lymphocyte population, seven had increased cytotoxicity values with both $T$ and non- $T$ cell subpopulations. Three patients had only $T$ cell and six only non-T cell cytotoxicity. In seven of the remaining 23 patients who did not show increased cytotoxicity with the undivided lymphocyte fraction, cytotoxicity was significantly increased with one of the subpopulations: non- $T$ cell in five cases and $T$ cell in two. Changing the method of preparing $T$ cells did not affect these findings. Thus $T$ cell cytotoxicity was observed in seven of nine cases in which the $T$ lymphocytes were prepared by removing cells forming EAC rosettes, and in seven of 10 cases in which the additional EA rosetting step was used.

No relation was found between the pattern of subpopulation cytotoxicity and histological categories (Table 2). The results, however, did seem to depend on the $\mathrm{HBeAg}$ status. The frequency of cytotoxicity with the undivided lymphocyte population tended to be slightly higher in $\mathrm{HBeAg}$ positive patients $(10$ of $21,48 \%$ ) than in those with anti-HBe (three of 10,30\%). When T-cell cytotoxicity was considered, this difference was more 
Table 2 Different combination of $T$ and non- $T$ cytotoxicity in various histological categories

\begin{tabular}{llll}
\hline & $\begin{array}{l}\text { T and } \\
\text { non-T }\end{array}$ & Only T & Only non-T \\
\hline Mild changes & - & - & 4 \\
Chronic persistent hepatitis & - & 1 & 3 \\
Chronic lobular hepatitis & 3 & 2 & 2 \\
Chronic active hepatitis & 4 & 2 & 2
\end{tabular}

apparent and statistically significant (10 of $21,48 \%$; and 0 of 10 , respectively; $p=0.008$ by Fisher's exact test). In contrast the frequency of non- $T$ cytotoxicity was not significantly different in the $\mathrm{HBeAg}$ positive and the anti-HBe positive groups (11 of $21,52 \%$; and three of $10,30 \%$, respectively; $p=0.27$ by Fisher's exact test).

The effect of changing the ratio of $\mathrm{T}$ lymphocytes to hepatocytes was studied in 11 cases, four of whom showed positive cytotoxicity at the standard ratio of $300: 1$. All four were also cytotoxic at a lower ratio of $100: 1$. In four patients in whom significant $T$-cell cytotoxicity was present after the standard 48 hour culture (mean \% cytotoxicity $\pm \mathrm{SD}=48 \pm 18$ ) similar values were recorded after the shorter 18 hour culture (45 \pm 10$)$. Attempts to examine T-cell cytotoxicity at six hours proved to be impossible because of poor attachment of hepatocytes in both control and test wells.

\section{TARGET ANTIGENS}

The effect of adding liver specific lipoprotein to the microtest wells was examined in 11 cases with increased non-T cell cytotoxicity. In all 11 , cytotoxicity values were substantially reduced and fell to within the normal range in nine cases. In contrast liver specific lipoprotein had little effect on T-cell cytotoxicity in eight cases tested (Fig. 2). The addition of aggregated IgG gave similar results: non-T cytotoxicity was blocked in five of six cases tested, whereas T-cell cytotoxicity was not significantly affected (Fig. 3). In three cases preincubation of the hepatocytes with the $F(a b)_{2}^{\prime}$ fragment of an antibody to human IgG blocked or reduced non-T cell cytotoxicity (Fig. 4). When purified $\mathrm{HBsAg}$ was added to the culture wells, there was a variable decrease in T-cell cytotoxicity, with results in five cases falling within the normal range (Fig. 5). Neither liver specific lipoprotein, aggregated IgG, nor HBsAg had a significant effect on autologous cytotoxicity in normal controls.

\section{Discussion}

These results show that about half of these patients with various types of chronic liver disease due to

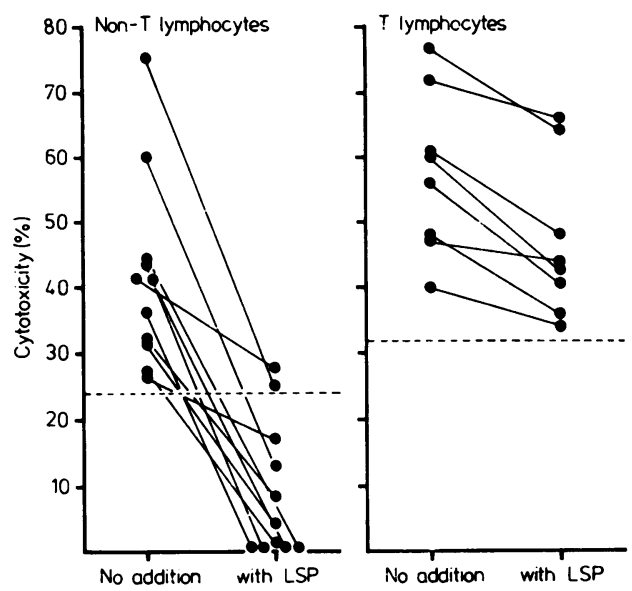

Fig. 2 Effect on non-T and T lymphocyte cytotoxicity of the addition of $1 \mu \mathrm{g}$ of LSP to the microculture wells.

hepatitis B virus infection have increased lymphocyte cytotoxicity to their own hepatocytes. Although there was no absolute correlation with histological appearances, the frequency of cytotoxicity was significantly greater in those patients with the most severe and progressive form of liver damage - that is, chronic active hepatitis. In most patients with increased cytotoxicity this was mediated by cells in both the $\mathrm{T}$ and the non- $\mathrm{T}$ lymphocyte preparations. Before assuming that both $\mathrm{T}$ and non- $\mathrm{T}$ effector cells are active in the assay, it is important to exclude the possibility that a non-specific effector
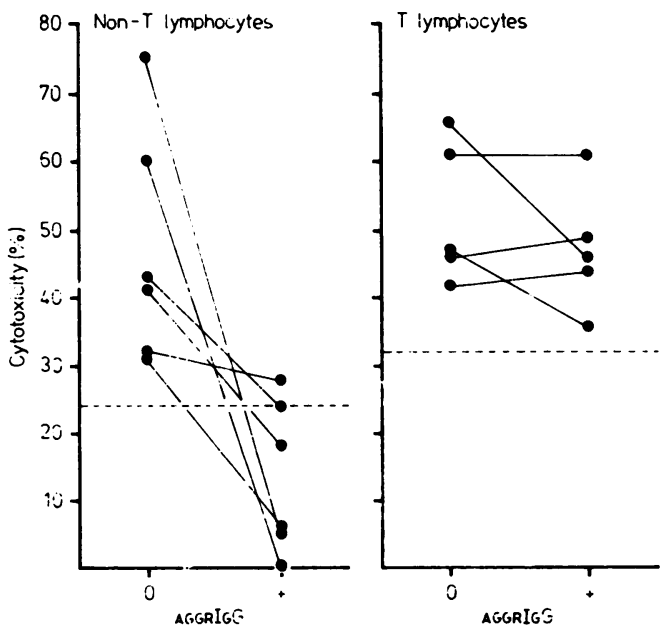

Fig. 3 Effect on non-T and T lymphocyte cytotoxicity of the addition of $5 \mu \mathrm{g}$ of aggregated IgG to the microculture wells. 


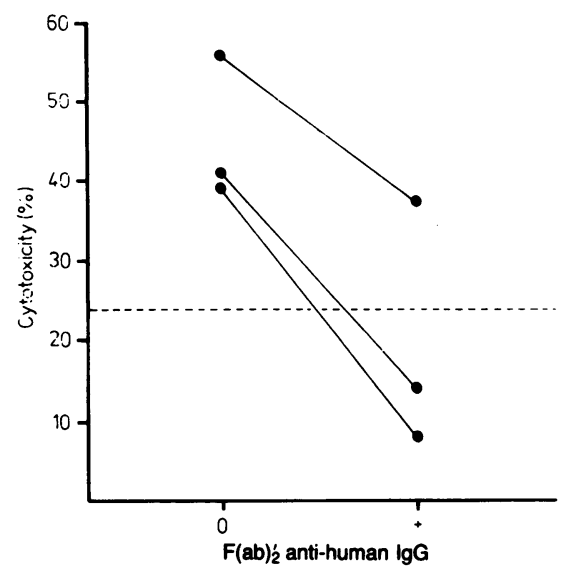

Fig. 4 Effect on non-T lymphocyte cytotoxicity of the addition of $12 \mu \mathrm{g}$ of an $F(a b)_{2}^{\prime}$ fragment of anti-human $\operatorname{IgG}$ to the microculture wells.

cell, such as a natural killer cell which could have been present in both subpopulations, is responsible for the damaging effect. With respect to the non-T population, the blocking experiments show that effector cells here have $\mathrm{Fc}$ receptors and when cultured with aggregated IgG or the $F(a b)_{2}^{\prime}$ fragment of an anti-human IgG the cytotoxic effect is markedly reduced, suggesting that this is due to an antibody dependent cell-mediated reaction. Furthermore, non-T cell cytotoxicity is blocked by

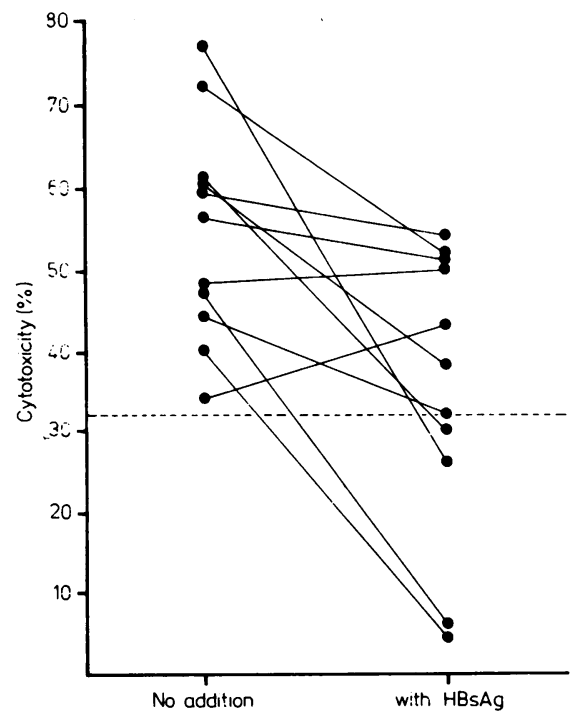

Fig. 5 Effect on T lymphocyte cytotoxicity of the addition of $0.5 \mu \mathrm{g}$ of purified HBsAg to the microculture wells. the addition of purified liver specific lipoprotein suggesting that the antibody in the antibody dependent cell-mediated reaction is directed at an antigenic determinant in the liver specific lipoprotein complex. Addition of aggregated IgG and purified liver specific lipoprotein had little effect on T-cell cytotoxicity, showing that a different mechanism must be involved. Natural killer cells, like $T$ cells, form rosettes with sheep red blood cells and lack complement receptors ${ }^{16}$ and may therefore be included in the $T$ cell fraction when the purification technique employed here is used. However, most natural killer cells seem to have Fc receptors and, as the removal of cells forming EA rosettes did not influence the results, it is likely that the cytotoxicity seen in the $\mathrm{T}$ cell fraction was truly an expression of $T$ effector cells. The results with a lower effector-target-cell ratio and a shorter incubation time are also consistent with the kinetics of a T cell response, ${ }^{17}$ although the effect of a six hour incubation could not be determined because of poor attachment of the target cells in both control and test wells. Liver specific lipoprotein was ineffective in blocking T-cell cytotoxicity, and, indeed, cytotoxic $\mathrm{T}$ cells reacting against unaltered cell components have never been demonstrated in man.

In experimental murine lymphocytic choriomeningitis, Zinkernagel suggested that T-cell cytotoxicity is directed against viral determinants expressed on the surface of infected cells, ${ }^{18}$ and such a mechanism could be operating in chronic hepatitis $B$ virus infection. Little is known of the antigens expressed on the surface membrane of hepatitis B virus infected liver cells, although $\mathrm{HBs} \mathrm{Ag}$ has been detected on the surface of hepatocytes early in the course of acute type B hepatitis. ${ }^{19}$ The addition of purified $\mathrm{HBsAg}$ to the microculture wells in this study resulted in only a partial block of $\mathrm{T}$ cytotoxicity. This could indicate that such cytotoxicity is not directed solely against $\mathrm{HBsAg}$ or that the addition of excess free antigen is inadequate to block T-cell killing. It is possible that the relevant membrane antigens appear only during active viral replication. Indeed, in our series none of the anti-HBe positive patients, in whom viral replication is likely to be low, had T-lymphocyte cytotoxicity, whereas this was present in about half of the $\mathrm{HBeAg}$ positive patients.

Our findings contrast with those obtained with this autologous cytotoxicity system in patients with 'autoimmune' HBsAg negative chronic active hepatitis. ${ }^{8}$ In those patients the cells responsible for cytotoxicity were always located in the non- $T$ cell fraction and only one patient also had increased cytotoxicity values with $T$ cells. Our results suggest 
that the liver-damaging immune mechanisms in chronic active hepatitis associated with persistent viral infection may differ from those in the 'autoimmune' cases. Whereas a non- $T$, antibody dependent cell-mediated mechanism seems to play a role in both subgroups and is directed at normal membrane components, $\mathrm{T}$ cell killing also contributes to cell damage in those HBsAg-positive cases in which there is active virus replication.

It is difficult to be sure of the pathogenic significance of these findings. It is unlikely that the results obtained are a totally accurate reflection of the situation in vivo, as it seems inconceivable that such a high percentage of liver cells are continually being destroyed in these patients, many of whom are virtually asymptomatic. Other factors such as the physical separation of effector and target cells by endothelial cells lining the liver sinusoids are likely to interfere with the cytotoxic reaction in vivo. In addition, in patients with chronic hepatitis B infection membrane bound IgG is found on many virus infected hepatocyte ${ }^{20}$ and is associated with a reduced membrane expression of $\mathrm{HBsAg}^{21}$ Reduced viral expression on infected cells could impair immune clearance by $\mathrm{T}$ lymphocytes in vivo. When the hepatocytes are cultured in vitro in the absence of patient's serum it is possible that this modulatory effect of antibody may be rapidly overcome; viral antigens could then reappear on their surface rendering them susceptible to T-cell damage. Such a sequence of events has been shown clearly for measles-infected HeLa cells. ${ }^{22}$

\section{References}

1 Wands JR, Isselbacher KJ. Lymphocyte cytotoxicity to autologous liver cells in chronic active hepatitis. Proc Natl Acad Sci USA 1975; 72: 1301-3.

2 Paronetto F, Vernace S. Immunological studies in patients with chronic active hepatitis. Cytotoxic activity of lymphocytes to autochthonous liver cells grown in tissue culture. Clin Exp Immunol 1975; 19: 99-104.

3 Wands JR, Perrotto JL, Alpert E, Isselbacher KJ. Cell mediated immunity in acute and chronic hepatitis. $J$ Clin Invest 1975; 55: 921-9.

4 Cochrane AMG, Moussouros A, Thomson AD, Eddleston ALWF, Williams R. Antibody-dependent cell-mediated ( $\mathrm{K}$ cell) cytotoxicity against isolated hepatocytes in chronic active hepatitis. Lancet 1976; 1: 441-4.

5 Perlmann P. Immune reactions in liver disease. Eddleston ALWF, Weber JCP, Williams R, eds.
Tunbridge Wells: Pitman Medical, 1979: 29.

6 Dienstag JL, Bhan AK. Enhanced in vitro cellmediated cytotoxicity in chronic heptitis B virus infection: absence of specificity for virus-expressed antigen on target cell membranes. J Immunol 1980; 125: 2269-76.

7 Zinkernagel RM, Doherty PC. Restriction of in-vitro T cell mediated cytotoxicity in lymphocyte choriomeningitis within a syngeneic or semiallogeneic system. Nature 1974; 248: 701-2.

8 Mieli-Vergani G, Vergani D, Jenkins PJ, Portmann B, Mowat AP, Eddleston ALWF, Williams R. Lymphocyte cytotoxicity to autologous hepatocytes in HBsAgnegative chronic active hepatitis. Clin Exp Immunol 1979; 38: 16-21.

9 Leevy CM, Popper H, Sherlock S. Diseases of the liver and biliary tract: standardisation of nomenclature, diagnostic criteria, and diagnostic methodology. Sponsored by the John E Fogarty International Centre for Advanced Study in Health Sciences and International Association for the Study of the Liver. Proceeding No. 22. Washington DC: US Government Printing Office, 1976: DHEW. Publication No. (NIH), 76-725, 9-11.

10 Rocklin RE, Meyer OL, David JR. An in vitro assay for cellular hypersensitivity in man. J Immunol 1970; 104: 95-102.

11 Böyum A. Isolation of leucocytes from human blood. A two-phase system for removal of red cells with methylcellulose as erythrocyte aggregating agent. Scand J Clin Lab Invest 1968; 21: Suppl: 97: 9-29.

12 McFarlane IG, Wojcicka BM, Zucker GM, Eddleston ALWF, Williams R. Purification and characterisation of human liver-specific membrane lipoprotein (LSP). Clin Exp Immunol 1977; 27: 381-90.

13 Verrier Jones J, Cumming RH. Standardisation of tests for immune complexes. In: Thompson RA, ed. Techniques in clinical immunology. Oxford: Blackwell Scientific Publications, 1977: 137.

14 Skelly J, Howard CR, Zuckerman AJ. The labelling of galactose residues in hepatitis B surface antigen glycoprotein. J Gen Virol 1978; 41: 447-57.

15 Farr AG, Nakane PK. Immunohistochemistry with enzyme labelled antibodies: a brief review. J Immunol Methods 1981; 47: 129-44.

16 Herberman RB, Djeu JY, Kay D, et al. Natural killer cells: characteristics and regulation of activity. Immunological Review 1979; 44: 43-70.

17 Cerottini JC, Brunner KT. Cell-mediated cytotoxicity, allograft rejection and tumour immunity. $A d v$ Immunol 1974; 18: 67-132.

18 Zinkernagel $\mathrm{RM} . \mathrm{H}_{2}$ restriction of cell-mediated virus specific immunity and immunopathology: selfrecognition, altered self, and autoaggression. In: Talal N, ed. Autoimmunity. London: Academic Press, 1977: 363-84.

19 Alberti A, Realdi G, Tremolada F, Spina GP. Liver cell surface localisation of hepatitis $B$ antigen and of immunoglobulin in acute and chronic hepatitis and in liver cirrhosis. Clin Exp Immunol 1976; 25: 396-402.

20 Trevisan A, Realdi G, Alberti A, Noventa F. Relationship between membrane-bound immunoglobulin and viral antigens in liver cells from patients with hepatitis 
1036 Mieli-Vergani, Vergani, Portmann, White, Murray-Lyon, Marigold, Woolf, Eddleston, and Williams

B virus infection. Gastroenterology 1979; 77: 209-14.

21 Alberti A, Eddleston ALWF. Determinants of chronicity in hepatitis B virus infection. In: Buckley RH, Doniach D, Fahey JL, et al, eds. Clinical immunology update. Vol. 3. New York: Elsevier
North-Holland. (In press.)

22 Oldstone $\mathrm{MB}$, Tishon $\mathrm{A}$. Immunologic injury in measles virus infection. Antigenic modulation and abrogation of lymphocyte lysis of virus infected cells. Clin Immunol Immunopathol 1978; 9: 55-62. 